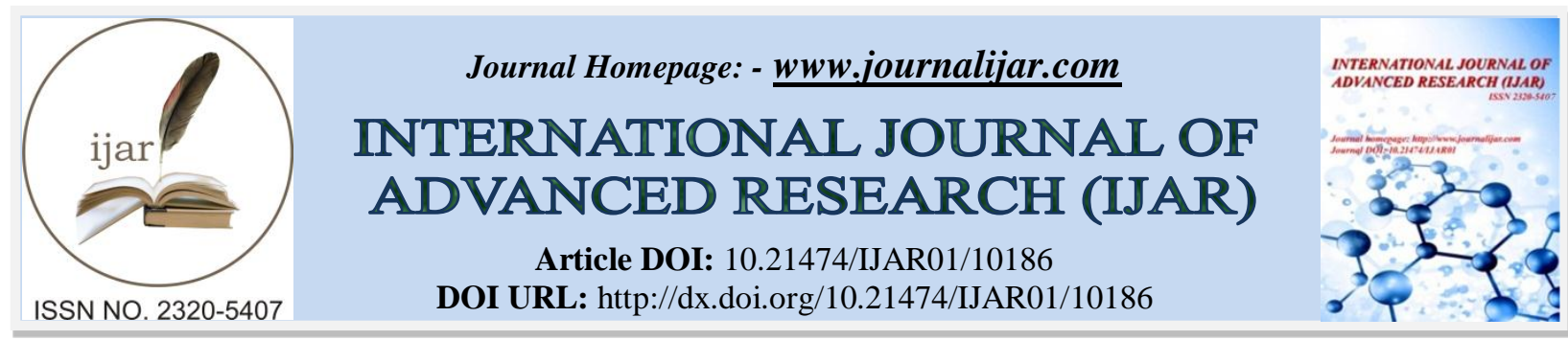

RESEARCH ARTICLE

\title{
LAW AND JUSTICE IN THE IMPLEMENTATION OF THE COURT IN EMPIRICAL PERSPECTIVE
}

\author{
Revency Vania Rugebregt
}

\section{Manuscript Info}

\section{Manuscript History}

Received: 08 October 2019

Final Accepted: 10 November 2019

Published: December 2019

Key words:-

Justice and Power

\section{Abstract}

The court is one of the state powers given the authority to uphold the law to achieve justice. It is said to be one of the tools of state power that is given the authority of law enforcement, because in addition to the court, then in the process of law enforcement there are still other state powers such as the police and prosecutors and executive institutions. Talking about law enforcement and justice in court, what is the substance of our discussion is the extent to which the process of law enforcement in a dispute or violations is the authority of the court to examine, try and make decisions to obtain justice in society.

Copy Right, IJAR, 2019,. All rights reserved.

\section{Introduction:-}

Law enforcement is one of the important parts of the process of achieving the goal of law to regulate life in society. With the end of lawmaking, the legal process will only complete one stage. Lawmaking must still be followed by concrete implementation in people's daily lives. That is what is meant by law enforcement. The court is one of the state powers given the authority to enforce the law in order to achieve justice. It is said to be one of the tools of state power that is given the authority of law enforcement, because in addition to the court, then in the process of law enforcement there are still other state powers such as the police and prosecutors and executive institutions. The difference between law enforcement carried out by the court and other law enforcement agencies such as the police and prosecutors must be preceded by a dispute or conflict from two or more parties or violations of the law, whereas law enforcement by the executive agency is part of its function to carry out various legal provisions.

Thus speaking of law enforcement and justice in the Court, what is the substance of our discussion is the extent to which the process of law enforcement in a dispute or violations is the authority of the court to examine, try and make decisions to obtain justice in society.

Such a scope needs to be placed because law enforcement and justice have a broad dimension both in terms of the legal instruments, the institutional dimensions that uphold them and the cultural dimension of the law (community). Thus if we talk about law enforcement and justice in the Court, then only a part of the substance of law enforcement and justice is seen, but even though it is only part of the study of law enforcement substance, the court is the last bastion of the process of law and justice enforcement. for justice seekers.

\section{Courts and Law Enforcement Processes:}

The court has a very important role in the process of law enforcement and justice. Because legally this institution was given the authority to enforce the law as an effort to seek justice. The court is an important element of judicial power as an independent state power to administer justice in upholding law and justice. In article 2 of Law Number 4 of 2004 concerning Judicial Power it is said that "the power of the judiciary is exercised by a Supreme Court and

\section{Corresponding Author:- Revency Vania Rugebregt}


judicial bodies that are under it in the general court environment, the religious court environment, the military court environment, the State Administrative court environment and by a Constitutional Court".

Thus in the context of law enforcement and justice in Indonesia today, the implementation of judicial power is carried out by two state institutions namely (1) the Supreme Court and the judicial body under it, and (2) the Constitutional Court. Each of these institutions has different functions and authorities from one another.

In article 11 of Law Number 4 of 2004 it says "The Supreme Court is the highest state court of the judicial environment under which the authorities:

1. adjudicate at the level of appeal against decisions rendered at the final level by the Courts in all judicial environments which are under the Supreme Court.

2. examine the statutory provisions under the law against the law.

3. other authorities granted by law.

In addition to the aforementioned authority, the Supreme Court exercises the highest supervision of court actions within the judiciary below it under the provisions of the law.

Meanwhile in Article 12 of Law Number 4 Year 2004 it is said "The Constitutional Court has the authority to adjudicate at the first and last levels whose decisions are final to:

1. examine the law against the 1945 Constitution of the Republic of Indonesia.

2. decide on a dispute over the authority of a state institution, the authority of which is granted by the 1945 Constitution of the Republic of Indonesia.

3. decide upon the dissolution of political parties

4. decide upon disputes over the results of general elections.

In addition to the aforementioned authority, the Constitutional Court is obliged to give decisions on the opinion of the House of Representatives that the President and / or Vice President are alleged to have violated the law in the form of betrayal of the state, corruption, bribery, other serious crimes or misconduct, and / or no longer fulfill requirements as President and / or Vice President. The key to the role of the court in law enforcement and justice is generally determined by the judge. This is due to the judge's position and obligation to uphold law and justice. Several matters related to the position and obligations of this judge, are clearly regulated in Law Number 4 of 2004 which among others confirms:

1. Judge is an official who exercises judicial power regulated in law (article 31) which is nothing but an independent power to administer justice in order to uphold law and justice based on Pancasila, for the implementation of the Pancasila rule of law (article 1);

2. Judges must have integrity and personality that are beyond reproach, honest, fair and professional and experienced in the field of law (article 32);

3. Judges are required to explore, follow and understand the legal values and sense of justice that lives in the community (article 28 paragraph 1 );

4. In considering the severity of a crime, the judge must also pay attention to the good and evil nature of the defendant (article 28 paragraph 2);

5. In carrying out their duties, the judge shall maintain the independence of the judiciary (article 23);

In addition, the position and obligations of judges are also regulated in the Honorary Code of Judges.

The main principle of the position and obligations as well as the code of honor of the judge is that in carrying out their duties, the judge must provide an impartial solution (not based on objective benchmarks based on applicable law, be independent and free from the influence of any party including from the government ${ }^{1}$. In this connection the French opinion of Bacon in Essays or Counsels of Civil and $\mathrm{Moral}^{2}$ that judges should be better educated (scholarly) than cleverly speaking, more useful than just being natural, and more aware of and knowing various relevant factors of the problems they face than beliefs. Above all they must have integrity and dignity, an important moral message that can be upheld in the performance of judges' duties. Thus, the judge has a great power over the parties with regard to problems or conflicts that are faced by him to decide ${ }^{3}$.

\footnotetext{
${ }^{1}$ Lubis Suhrawardi K, 2000, Etika Profesi Hukum, Sinar Grafika, Jakarta Hal 25

${ }^{2}$ Arief Sidartha, 1992, hal 1111

${ }^{3}$ Mochtar kusumaadmadja, 1974, konsep konsep hukum dalam pembangunan, pt alumni, bandung, hal 17
} 


\section{Empirical Review of Law Enforcement and Justice by the Court.}

The coming into effect of Law Number 22 of 2004 concerning the Judicial Commission amended by Law Number 18 of 2011 in addition to constitutional demands as regulated in article 24B of the 1945 Constitution of the Republic of Indonesia, but on the other side in terms of its authority, the implementation of judicial power which is carried out through a judicial body which is carried out on a daily basis by Judges who are expected to be free and independent without being influenced by any power, can finally be controlled in the context of upholding and dignity and maintaining the judge's behavior.

In this regard, the critical question that needs to be addressed is "is the severity of the dignity and behavior of judges, so that they need to be upheld through the control of the Judicial Commission?" This question is not difficult to answer, because according to the Judicial Commission in a year 50\% more than 754 cases of judge decisions in Indonesia show that the judges are not independent or as said by A. Mukti Arto that of about 14,677 civil cases in 1997, it turns out that $90 \%$ of them were requested appeal. It is not known with certainty what caused the Judicial Commission or A. Mukti Arto to finally make such a conclusion. However, it is at least predictable that until now the Court through its judges, which should have played a role as one of the institutions given power in the process of law enforcement and justice, has not yet carried out its functions optimally. Several factors that have been assessed as having an influence on the independence of the Court / Judge in law enforcement and justice efforts, include:

\section{Influence of power and politics:}

Power and politics are important in the process of law enforcement and justice. The law requires coercion for the arrangement of the provisions or the law requires force for enforcement. The law also requires political power in the process of stipulation / ratification. However, although the law requires power for the process of making / ratification and enforcement through legislative institutions and other law enforcement agencies (police, prosecutors, judges, lawyers, etc.), but in reality power often influences the process of law enforcement itself. The influence of political power on law enforcement and justice processes (more specifically in court) can be seen in several ways as follows:

1. There are still judges / courts that are often influenced by political power, including from the government;

2. Judges / court decisions that often consider the influence of the powers / positions of certain people;

3. Judge / court decisions that often consider the political impact of a case;

\section{Materials:- \\ The effect of money:}

Money and or material is something that is very important for human needs. Associated with the process of law enforcement and justice in the Court, this is not a public secret. Moreover, this is often associated with the welfare of judges (salary or functional allowances of judges) which are considered inadequate. This condition is further exacerbated by the involvement of legal aid providers who do not hesitate to put money and / or material as the main compensation in resolving a case. Phrases such as the Criminal Code (Love of Case Money) or the Judgment (Contact Me if You Want to Win) is an adegium that causes money and / or material as a determinant in the process of law enforcement and justice in the Court.

\section{Judge's psychological condition:}

In handling various cases in court, judges often receive threats or terror from certain parties. Threats or terror can affect the judge's independence in decision making, if the judge does not have the courage to face the threat. This is also due to the fact that the judges have not yet obtained maximum legal protection in carrying out their duties.

\section{Professionalism of judges:}

In many cases that were tried by the Court there were still judges' decisions which were finally judged by justice seekers as non-independent decisions. This is not caused by the influence of power / politics, money and or material and threats, but is caused by a lack of professionalism from the judges themselves. In carrying out their duties, judges are required to explore, follow and understand the legal values that live in society. This obligation can only be carried out properly if the judge can be professional in carrying out their duties. In reality, it is still found, judges in deciding a case do not follow carefully, understand well the developments that occur in the middle of society (written and unwritten legal developments, new findings through doctrine, jurisprudence and other legal sources) including efforts to continue to explore legal values that live according to culture and customs in the midst of society are expected to be a source of new law through jurisprudence. This is important because the law on the one hand is 
expected to be a means of social engenering, but on the other hand the law is still often lagging behind developments in the midst of society. This fact is also observed in observations due to the existence of procedural law provisions that have increasingly been left behind as is the case in civil cases, where judges are more passive. This attitude will only limit the judge in deciding a case based solely on legal facts through evidence submitted by the parties without any attempt to dig deeper.

\section{Role of Judicial Commission:}

The Judicial Commission as an independent institution that functions in the process of appointing judges and as an institution that carries out control functions to safeguard the honor, dignity and behavior of the Supreme Court Justices and Judges, was introduced and recognized for the first time in the third amendment to the 1945 Constitution which was then formulated into article 24B. Further elaboration on the provisions of Article 24B of the 1945 Constitution is then poured into Article 34 of Law Number 4 of 2004 concerning Judicial Power and Law Number 22 of 2004 which has been amended by Law Number 18 of 20011 concerning the Judicial Commission. By noting that in carrying out the duties of the Judicial Commission, where the Judicial Commission can (a) receive public reports on the behavior of judges; (b) requests periodic reports to the judiciary regarding the conduct of judges; (c) examine the alleged violation of the judge's behavior; (d) summon and request information from judges suspected of violating the judge's code of conduct; (e) make a report on the results of the examination in the form of a recommendation and submit it to the Supreme Court and / or the Constitutional Court, as well as the copies delivered to the President and the Parliament (article 22) and the proposal to impose sanctions on judges (article 23 paragraph 2), so this can minimize various factors which have so far been considered to be influential in the implementation of Judges' duties in the context of law enforcement and justice.

However, there are several issues that need to be criticized going forward about the role of the Judicial Commission, including:

1. The Judicial Commission is a new state institution whose community is not widely known, including its duties and authority. Therefore in the future socialization of this institution is needed along with its duties and authorities to the community;

2. The Judicial Commission is a state institution domiciled in the national capital. However, the operationalization of the implementation of the tasks of this institution is more in regional areas, where taking into account the geographical conditions of Indonesia, this institution should be able to open access to the region, bearing in mind that those who seek justice add more transparent law enforcement and justice from the court. Therefore in the future the Judicial Commission needs to open up wider opportunities with the people in the regions to access various violations committed by judges related to law enforcement and justice in the courts through collaboration with various social institutions, NGOs, universities and so forth.

3. Publication of various results of activities relating to the implementation of the duties of the Judicial Commission that are easily known to the wider community, will certainly have a positive impact on efforts to maintain and improve the dignity, dignity and honor of judges in the process of law enforcement and justice, while helping to open public insights .

\section{Closing:}

From the description described above, it can be concluded the following matters:

1. Enforcement of law and justice in court is the desire of the people because the court through the judges not only functions to uphold law and justice, but also the court is the last bastion for justice seekers to seek justice (although it is not true justice).

2. Although the hope remains in the court, the court through the judge is considered not to uphold the law and justice maximally as a result of various factors that influence it, such as the influence of political power, the influence of money and / or material, the psychological condition of the judge in facing threats or terror and the professionalism of the judge himself, in addition to the provisions of the procedural law which are considered out of date and guarantee legal protection for the judge in carrying out their duties has not been maximized.

3. The presence of the Judicial Commission as a state institution with a special identity in the context of supervision (control) to judges is a solution to minimize various violations in the process of law enforcement and justice in court, as well as efforts to maintain and improve the dignity, dignity and honor of judges in the process law enforcement and justice. 


\section{Based on these conclusions, it is recommended:}

1. The provisions of formal law (procedural law), especially civil procedural law, do not provide opportunities for judges to develop their professionalism in exploring, understanding and following the development of the legal values that develop in society, it is time to change.

2. To maintain and improve the dignity, dignity and honor of judges in the process of law enforcement and justice, it is necessary to provide maximum legal protection for judges in carrying out their duties.

3. Optimizing the role of the Judicial Commission especially in the context of supervision (control) for judges needs to be followed up with:

4. Dissemination of the Judicial Commission institutions and their duties and authority to the public at large.

5. Open access to the regions through cooperation with various social institutions, NGOs, universities and so on.

6. Widely publicized to the public about the results of the implementation of the tasks of the Judicial Commission.

\section{References:-}

1. Undang Undang Dasar Negara Republik Indonesia 1945

2. Undang Undang Nomor 4 Tahun 2004 Tentang Kekuasaan Kehakiman

3. Undang Undang Nomor 22 Tahun 2004 Tentang Komisi Yudicial.

4. Arto A. Mukti, 2000, Mencari Keadilan, Pustaka Pelajar, Yokyakarta

5. Mochtar Kusumaadmadja, 2002, Konsep Konsep Hukum Dalam Pembangunan, PT Alumni, Bandung

6. Hengky Hattu, Makalah Disampaikan pada Lokakarya \& Seminar Partisipasi Publik dan Optimalisasi Kontrol Masyarakat Terhadap Penegakan Hukum Oleh Peradilan Yang Efektif dan Efisien di Daerah Dalam Meningkatkan Harkat, Martabat dan Kehormatan Hakim, kerjasama Pusat Kajian Konstitusi Fakultas Hukum Unpatti dan Komisi Yudisial Republik Indonesia)

7. Lubis Suhrawardi K, 2000, Etika Profesi Hukum, Sinar Grafika, Jakarta

8. Satjipto Rahardjo, 2000, Ilmu Hukum, PT Citra Aditya Bakti, Bandung. 